\title{
Sciendo
}

\section{REFLECTIONS ON RESEARCH IN ROMANIA}

\section{SAM BECK 1}

\begin{abstract}
This is a biographical account of my work in Romania and the influence it had on my research that followed. I focus on the impact that my almost five years in Romania had on the framework and orientation of my anthropological practice that I employed in the United States. I suggest that anthropologists have a moral imperative we must carry out when we choose to conduct research among the most vulnerable in society. In doing so, we must also come to understand the conditions that have made them vulnerable in the first place (Nader 1969). I assert here that as anthropologists of the twentyfirst century we no longer may stay on the sidelines, but we must engage our work as allies with the vulnerable, supporting them in their self-identified struggles for dignity, liberation, and sustainability as part of a unified global effort. This entails the transformation of participant observation into a participatory research approach.
\end{abstract}

Keywords: biography, critical anthropology, participatory action research, UMass Romanian Research Group

"What if we use theory and method to benefit the people we study by partnering with them to move towards a just world, one where inequities are reduced where there is greater access to knowledge gained from anthropological research? To reach this goal anthropologists must play a more intentional and responsible role in working with people, communities and movements - the stakeholders with whom research is carried out. [...] We must participate in generating and bringing about change. We must engage in protecting the most vulnerable from oppression and exploitation and support the empowerment of communities to improve people's lives. This is a role not comfortably taken by tradition-bound anthropologists; however, an engaged stance moves the application of anthropological theory, methods and practice further along towards action and activism. At the same time, engagement moves anthropologists away from traditional forms of participant observation towards a participatory role by becoming increasingly a part of those communities or social groupings that we normally study" (Maida and Beck, 2013).

\footnotetext{
1 Practicing Medicine Program, College of Human Ecology, Cornell University,
} e-mail:sbeck@med.cornell.edu. 


\section{The Beginning ${ }^{2}$}

From faded memory and without the benefit of field notes ${ }^{3}$, the following is an account of my work in Romania and the impact it had on my research that followed. I appreciate having been asked to address the work I carried out in Romania, initially as part of the University of Massachusetts Romanian Research Group and then on my own. I take this opportunity to focus on the impact that my almost five years in Romania had on the framework and orientation of my anthropological practice that I employed in the United States. I also take this opportunity to suggest that anthropologists have a moral imperative we must carry out when we choose to conduct research among the most vulnerable in society. In doing so, we must also come to understand the conditions that have made them vulnerable in the first place (Nader, 1969). I assert here that as anthropologists of the twenty-first century we no longer may stay on the sidelines, but we must engage our work as allies with the vulnerable, supporting them in their self-identified struggles for dignity, liberation, and sustainability as part of a unified global effort. This entails the transformation of participant observation into a participatory research approach.

In August of 1973, after two months of pre-dissertation research in Rosenheim, Bavaria investigating Yugoslav Gastarbeiter (funded by the Deutscher Akademischer Austauschdienst), I joined John W. Cole and David Kideckel in Brașov to explore Județul Brașov for sites where we and Steven Randall, Steven Sampson, and Marilyn McArthur would eventually settle to carry out our respective doctoral fieldwork.

I was thoroughly frustrated and perhaps even repulsed by what was a very unhappy field experience in my attempt to track Yugoslav Gastarbeiter social relations and movements. It was not the Yugoslav workers that bothered me, but the conditions under which they worked and lived to improve their lives and those of their loved ones back home in Yugoslavia, a relatively short train ride away. To increase their savings, which was remitted home, they lived sparse lives, housing themselves dormitory style and rarely eating hot meals in restaurants. It was not the kind of fieldwork I had hoped for.

\footnotetext{
2 I dedicate this account to two people: John W. Cole, my graduate school mentor, provided me with the foundations for my form of critical anthropology in teaching, scholarship, and activism while Nicolae Gheorghe modeled for me an activist and participatory approach to fieldwork and knowledge production. Steve Sampson offered some critical remarks that brought me to clarify my thoughts. Alas, I did not follow all his suggestions for this article, but I still am grateful for his careful reading of the text and his thoughtfulness. I also want to thank Carl Maida for his persistent support and encouragement. Marianne Cocchini is the bedrock of any of my accomplishments: my thanks and love to her. Any failings in this text are my own.

${ }^{3}$ My research notes and much of my Romanian materials were lost due to a series of basement floods, leaving me with my memory of events experienced decades ago.
} 
Our research model in Transylvania was based on the cultural ecology study of Puerto Rico carried out by Julian H. Steward (1956) and his team in which participants were situated in different locales and different parts of the main island. John Cole's work with Eric Wolf of the Italian Alps (1974) also served as the conceptual context of how the Romanian Research Group imagined the unfolding of our work informed by cultural ecology, political economy, and world systems theory. I would be remiss in not also mentioning the impact Dell Hymes (1972) and Fredrik Barth $(1961,1969)$ had on me.

I read furiously in the literatures focused on modes of production, such as Barry Hindes and Paul Hirst, Perry Anderson, Lawrence Krader, and Harold Wolpe; I delved into the works that focused on development and underdevelopment especially Andre Gunder Frank, Walter Rodney, Immanuel Wallerstein, Daniel Chirot and Fernand Braudel, among others. Of course, Keith Hitchins' book on Transylvania was important. I read Christopher Hill, Rodney Hilton, and Eric Hobsbawm and feminist works by Sheila Robotham, Michelle Rosaldo, Louise Lamphere, and Rayna Rapp.

While each of us situated ourselves in a community study, our interests focused on the processes, forces, and conditions the State had on these communities. Our research strategy sought out the impact of actually existing socialism on local level village life and the impact of villagers on actually existing socialist policies as these were practiced. Yet, as anthropologists well know, research directions take on a life of their own when experiences in the field convey what is deemed important or interesting, redirecting and focusing our work.

Starting in 1974, the Romanian Research Group spread out on the inner western flank of the Carpathian Mountains within the Transylvanian arch in Județul Brașov. We purposefully stayed away from settlements with Hungarian speaking populations that would signal to Romanian authorities an attempt to investigate or inflame inter-ethno-national hostilities. Romanian leaders had a heightened awareness of Transylvania's complex ethnic mix linked with not unfounded geopolitical aspirations of neighboring nation-states and a fervor to maintain the integrity of Romania's borders.

Steve Sampson and Marilyn McArthur settled into multicultural Feldiora. Steve focused on Romanians and Marilyn, as a German speaker, on Saxon Germans. The "repatriation" of Volks Deutsche, the Saxons, to West Germany made Transylvanian Saxons no threat. They were abandoning their Siebenburgen homeland significantly thinning out their centuries-old settlements, their churches and fortified villages and towns. David Kideckel chose to work in Hîrseni not far from John Cole, who chose Mândra, settlements organized into agricultural collectives that are part of Țara Făgărașului and its culture area. Steven Randall and I settled into Poiana Mărului, an upland area situated between 
two culture areas, Țara Făgărașului and Țara Bârsei. Randall decided to live in the sparsely settled part of this dispersed mountain community, oriented toward Țara Făgărașului. He lived in an upland farmstead. I decided to live in the village center some distance away from him, oriented more toward Tara Bîrsei that sustained community life, where the mayor's office, the school, the church, a cafébar, a medical clinic, a dentist's office, a general store and the village smithy were located. Just about everyone in the village center had land they farmed, a steep walk away. Most held rights to multiple properties, dispersed across the hilly upland terrain due to inheritance prescriptions over the generations dividing property among descendants.

It was John Cole's idea to develop the project in Romania. With funding from the University of Massachusetts-Amherst, Department of Anthropology, a Ford Foundation Soviet Union and Eastern European Research Grant, and International Research and Exchanges Board (IREX) grants that each of us received, all of us started our projects in Romania. It was John Cole, as the Director of the Romanian Research Group, who involved himself in the negotiations with the authorities.

Speaking for myself, I maintained as little contact with authorities as possible and reported in when asked to do so. The exchanges that took place in Bucharest, as I remember them now, were relatively brief and perfunctory. At the time, it seemed to me that the person to whom I reported was actually not particularly interested in what I was doing and I was not particularly interested in relaying information. I spent weeks in Poiana Mărului periodically meeting with John and group members in Brassov, when we were all in Romania together. On those occasions, we treated ourselves to hotel living and restaurants with large menus that would not have most items listed and when a waiter was asked about a menu item, he inevitably responded with, nu avem! Still, we ate well. I remember the feeling of taking a bath, a luxury I did not have in the village. I do not recall visiting colleagues in their respective villages. From time to time, Steve Randall came to visit me and to buy a loaf of bread.

When I first arrived, the local authorities were at a loss as to what to do with me. I spoke virtually no Romanian and no one in the community spoke passable English. After most of the day spent in the primărie (the village administrative center) as night approached, I was directed to the local cârciumar (barkeep), Ionică Clopoțel, who put me up in a spare room used for storage with a window that faced the asphalted road. Concerned that no one would want to put up with an American who could not speak Romanian, I was glad to have been assigned a home, even though it was a cold room used for storage with a bed. Over the course of months, the asphalted road, this sparsely travelled thoroughfare for which I had a view from my window was my companion as the asphalt sang when trucks drove by in the evenings as I typed up my notes at night. 
The arrangement that was made for me that day settled me into Clopotel's three-room household on one side of the creek that ran through the village and on the other side I crossed on a little bridge to have lunch and dinner with the Ioan Meleacha family where doamna Meleacha was well known for her cooking skills. Each household was paid a stipend, the value about which I was never informed, nor did I ask. This arrangement gave me access to two very different households who, among other work activities, maintained privately owned, dispersed plots of farmland and animals. Each had their houses in the village center, most of which were three-room structures with an enclosed courtyard dating back to the middle of the nineteenth century. The Clopotels had no children, but adopted and raised a girl, a young woman at the time who spoke little, did much of the household chores and worked the farmland with Măruța Clopoțel's father, Barbu. Ionică and Măruța Clopoțel left the girl the sole inheritor of their substantial properties. Barbu lived some distance away at the top of an incline that left me breathless when I sought to visit him. He lived in a structure split in two; one-room housed him. The other room was the barn. The Meleachas had two daughters, the oldest of which was married and lived in Brașov, and a son, Mihai. It was Mihai, in his early twenties, who formed a close relationship with me. He worked in the Zărnești bicycle factory (I herd that armaments were being manufactured there) and, when home, he reluctantly worked the fields, some distance away in the uplands, with his father and older unmarried sister in her late twenties. In his leisure time, Mihai occupied himself with consuming copious amounts of alcohol to dull his senses because, as he told me, he hated his life. The Clopoțels worked hard, like everyone with whom I had contact, working the café-bar and farming their holdings. They raised two pigs every year in the back of the house, memorable to me because two of them, whom I named Fanny and Zooey, before their demise would grunt and rub their backs on the post that helped support the outhouse, where I used to relieve myself, shaking the entire structure.

One central overarching theme that our team shared was the relationship of our respective villages with the socialist state. As I prepared for research in the Balkans back in Amherst, my interests focused on transhumance sheep and goat herding, an interest that derived from a two-year research project among pastoral nomads of Iran (1969-1972) and my undergraduate year abroad in Zagreb, Yugoslavia. Once in Poiana Mărului, I quickly learned that this form of herding no longer existed in the village and as a result, over time, I reoriented my focus of research to the social history of these ethnic Romanian inhabitants' adaptation to their mountain environment and their relationship to the surrounding areas. 


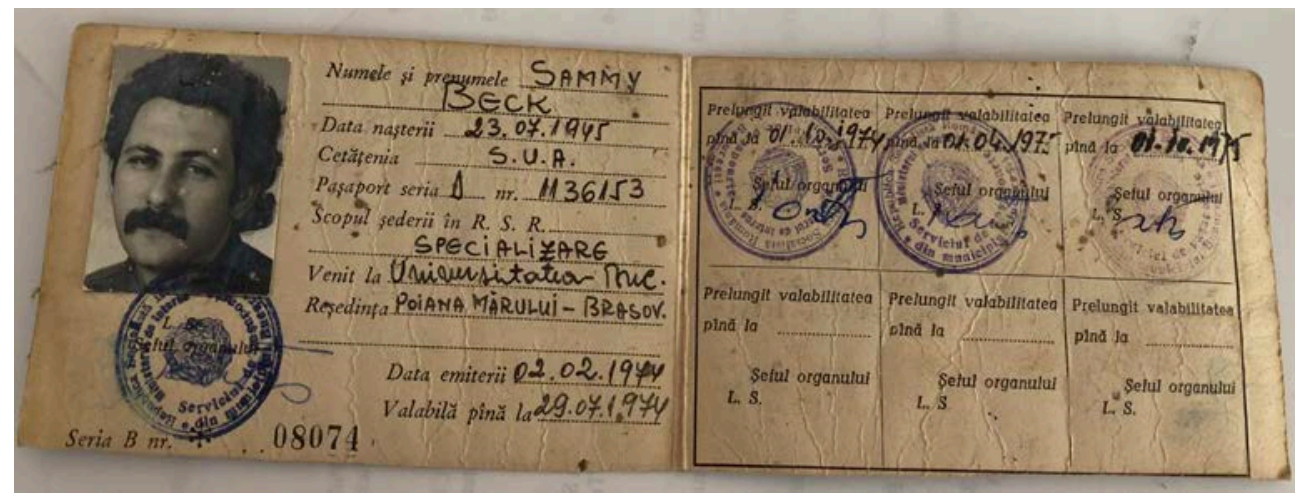

Romanian identification card. Source: Author's archive.

\section{Romanticism}

In 1973, when I got to Romania, getting off the train in Brașov and then touring the countryside with John and David, my sense of "this is what doing fieldwork is about" came rushing in. As we drove into Poiana Mărului from Zărnești toward Șinca Nouă and Țara Făgărașului, the contrast with my Rosenheim experience was stark. In my mind's eye, the Poienari fit the classic peasants living in what at first sight seemed like a relatively isolated settlement with most of its inhabitants spread out on bucolic hills dotted with dispersed households. It was astonishingly breathtaking on that warm, sunny summer's day we visited the village center. I was smitten.

When I settled in months later, in 1974, and became more fluent in Romanian, I spent much of my time in the cârciuma (café-bar), operated by Ionică and Măruța, chain drinking țuica and coffee and smoking Carpați cigarettes throughout the day, eating lunch with the Meleacha family, visiting Dr. Barac in the doctor's office, chatting with him or with his nurse and nurse's assistant and drinking ever more Turkish coffee, and then having dinner with the Meleachas, discussing the day's events and watching TV with them until it was time to sleep. Ionică and Măruța were well placed in the village, privy to all the gossip, even from the more distant households because just about all the men who either lived in the village center or came there from their upland homes came to the cârciuma to have a drink and a cigarette.

I spent quite a bit of time with the village priest, părintele Gigi, whose father was priest in the village before him. He lived in the largest house in the village near the church with his wife and mother. He invited me to accompany him to funerals that took place in every part of Poiana, sometimes walking many 
miles to get to one of the more distant households where funerals took place. I was always invited to virtually all lifecycle events, baptisms and marriages included, held in the village and among scattered homesteads in walking distance from the village center. In this way I got to know about the various families and their kinship ties and often found out about the properties over which each household claimed ownership. In the evenings, Ionică and Măruța would clarify these relationships for me, often treating me with bulz (mămăliga cu brânză) or a fried pork chop.

I attended weddings that lasted three days of eating, dancing, drinking, lots of drinking, held in the village hall available for such events. I spent time in the primărie (the village administrative center) looking over the Austrian land cadaster map, a complex matrix of plots that over time got smaller and larger as each household sought to bring their properties as close to each other as possible and as inheritance redistributed land to the next generation in smaller parcels.

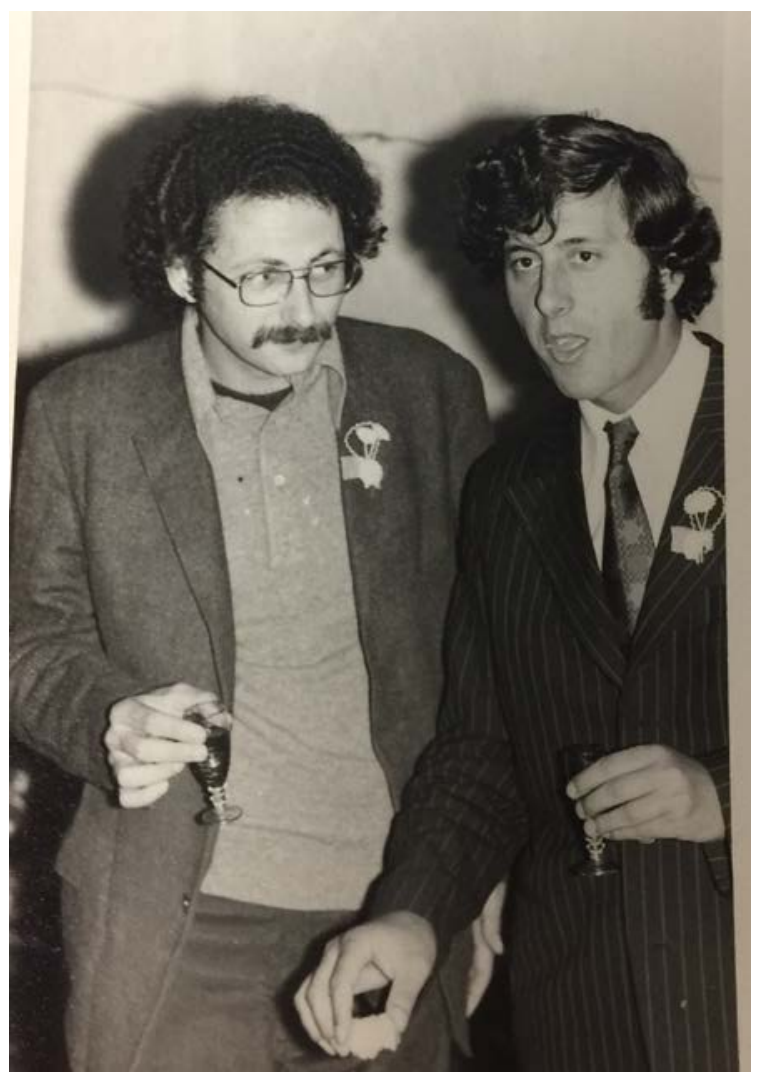

At a wedding. Source: Author's archive. 
I went to church each Sunday and always was given a place in the front, close to părintele Gigi who would hand me the incense burner to hold. I delighted him the first time he handed it to me because I held it too close to my body allowing the incense smoke to rise to my face. I remember him waiting for this moment and smiling as I paled, grew nauseous, and raced out of the church. Later he instructed me to hold the object away from the body.

Over the course of my Poiana Mărului fieldwork, I knowingly had little contact with what I would call the authorities in the village. There was the primar (mayor) who was from Șinca Nouă, part of the Poiana Mărului administrative unit, and the activist de partid (party member), one notably short young man who had one leg shorter than the other and walked with a limp. He taught in the village school. I rarely saw them. This is not to say, people with whom I had contact were not informing on me. I suspected officials such as the doctor and his staff, the priest, and then of course my hosts. However, I decided that whatever I was doing during fieldwork was not something that should be of concern and would not need any precautions. Besides, what did I gain from spending my time being paranoid. Years later I received part of my Securitate file that listed dozens of names of individuals who apparently informed on me.

\section{Ethno-nationalism}

As weeks turned into months, I became increasingly aware of how Romanian socialism portrayed itself in the face of its neighboring nation-states and the critical importance of Transylvania (Romanian: Ardeal) as Romanian and certainly not Magyar (Hungarian), nor German (German: Siebenburger Sachsen; Romanian: Sași). Who occupied Transylvania first Romanians or Hungarians loomed large in the controversy of the Hungarian and Romanian states. After all, it was only after the 1918 Treaty of Trianon that Transylvania became part of the Romanian Kingdom, removed from Hungary. Things could always shift back.

Geza II of Hungary had settled Germans to protect the southeastern part of the Hungarian Kingdom in the $12^{\text {th }}$ century to defend Transylvania from incursions by marauding Asiatic groups. A Hungarian Border Guard made up of Magyar speakers, the Szekely, were positioned in the southeast, as were the Teutonic Knights of Tara Bârsei who built a number of castles and cities, including Brasov. I became fascinated by this history and the complexity it represented as I tried to grasp the lives of the Poiana Mărului ethnic Romanians under conditions of socialism. As I continued my study in the writing of my dissertation I was struck by the importance Romania gave to the first occupation of these lands by Romanians and how this contributed to the construction of a Romanian identity and the sense of continuity so important to the state. 
In some ways, not collectivizing a mountainous settlement like Poiana Mărului was not only about the fact that mechanizing agricultural land on steep slopes was next to impossible with the technology the Poienari had available. There was an ideological value to having Romanians in the uplands and uncollectivized. They pointed to continuity, a history of ethnic Romanians occupying the uplands seasonally as they tended their animals there and reproduced their "traditional" way of life over the centuries. Hungarians could claim that when they entered Transylvania the land was "empty," unoccupied. Romanians could claim that they occupied the uplands grazing sheep in the summer and the lowlands in the winter.

Yet, clearly, the socialist economy had an impact on these upland dwelling peasants. Their agricultural production had to serve the interests of the state, each household producing pigs, cattle and milk based on a quota system. The other significant impact on them was the expectation, if not the rule, that each household would contribute individuals to industrial labor. I wrote The Emergence of the Peasant-Worker in a Transylvanian Mountain Community (1976) to address what I was observing. The men and some women left their homes early in the morning when the sky was still dark to participate in industrial work and returned when it was dark. There was a night shift as well. They worked their land, tended to their animals and held factory jobs.

My doctoral work, Transylvania: The Political Economy of a Frontier (1979), resulted from more than two years of living and being in this village with which I fell in love and two years of historical research afterwards. This work was an attempt at coming to terms with Poiana Mărului's social history the construction of which was based on much excellent Romanian scholarship produced during the inter-war period. I discovered the richness of the research carried out by Dimitrie Gusti's students and colleagues who formed the Bucharest School of Sociology. In referring to Gusti and his many students about whom much should be known outside of Romania, I can only indicate here that their social scientific achievements in a real way preceded what we now identify as interdisciplinary and multidisciplinary team research that incorporates those researched into their projects in a participatory action research (PAR) manner. The teams carried out fieldwork much like anthropologists today making firsthand observations and interviewing local people about their lives and customs. Moreover, they carried out their work not only to document a way of life, but they were also intentional about improving the lives of the people with whom they worked, what today we call engaged anthropology. Of course, the focus on traditional forms of Romanian culture and life before the Second World War was about the formation of a united Romanian national identity and nation-state building and Gusti's work contributed to this effort. 
Some fascinating, mostly older, ethnic Romanian scholars were advising us in this early period and during my second fieldwork. When I visited Bucharest, mostly to gain respite from being in the field and to acquire advice, I was intellectually inspired by the wisdom of scholars like Romulus Vulcănescu, Traian Herseni, Mihai Pop and Henri Stahl. I also had the opportunity to interact directly or through correspondence with a number of still surviving scholars of Gusti's students. Often enough, these senior scholars fed me at their table. Mihai Pop always plied me and my colleagues, when we visited him together, with palinca from Maramureș, of which he seemed to have an endless supply. Rarely did I leave his wonderful home with a clear head and without stumbling out the door!

Upon completion of my doctoral dissertation, I returned to Transylvania to investigate economic specialization in Țara Făgărașului. I decided to settle in Şercaia (German: Schirkanyen), located on a major thoroughfare connecting Brașov with Făgăraș and Sibiu. At the time, it was a mixed village of Romanians, a decreasing number of Saxon Germans, and an increasing number of Roma ${ }^{4}$. It was slated by planners to grow into a town with an increasing population and an expanded economic base. My thoughts at the time about choosing Șercaia were that I would easily visit all the villages located within Țara Făgărașului from this central spot. I chose to live with a Saxon extended family because I spoke German and I could gain an understanding of ethnic Romanians through different lenses. I came to live with Karli and his extended family. I could also gauge the changes of territorial de-Germanization, as Saxons, like this family, were in a holding pattern waiting to migrate to West Germany while Romanians and Roma took ownership of the properties left behind by them.

\section{Nicolae Gheorghe and the Roma}

I lived in a room with a bed and a leaky potbellied stove, a small structure separated from the main house within the Saxon Hof. This gave me a degree of privacy, although the family always invited me into the main house for meals and drinks. Most evenings ended with alcohol consumption and the singing of songs, many of which resonated with the past when Saxons held high status before and during the Second World War and the hardships they experienced after the war as forced laborers in the Soviet Union. They sang songs of the years in Soviet labor camps, mostly to the Ukrainian SSR, to which

\footnotetext{
${ }^{4}$ I use the term "țigani" as a colloquial term, as Romanians would use it, and how many Roma I spoke with identified themselves. In popular language "țigani" is a slanderous term that unless I indicate popular usage, I replace it with "Roma", a politicized term that the Roma intelligentsia is using to create unity.
} 
they were deported (der Verschleppung). As planned, I used my housing as a base from which I started my travels to investigate Olt valley villages. As I moved about, I could not ignore that all the villages I visited had Roma living on the outskirts in abject poverty.

This had also been the case in Poiana Mărului where four or five hovels were located along a tributary that fed the village creek. When the weather was warm, a middle-aged woman sat in the doorway of one of these making baskets. I bought a small basket from her, in my possession to this day. Her husband, an industrial worker, would trudge off daily to Zărnești returning home in the evening. When I passed by near the embankment where they lived, I saw children playing near these hovels, covered in dirt and dressed in rags. At the time, I noticed them but paid little attention to their plight. The Poienari Romanians looked upon them with disdain and called them tigani. The Poienari referred to one particular family that lived in the village center who I assumed was ethnic Romanian as țigani as well. This puzzled me for some time. Much later as I came to research Roma, I understood the use of the term much better. Tigani could be used as an ethnic label, but more often it referred to their lowcaste status and the slovenly way in which they lived. I perceived the term's use similar to the "N word" used in the United States.

When visiting Bucharest sometime in my second year in Romania, I ran into Nicolae Gheorghe with jet-black hair and dark skinned. We decided to meet over coffee and share our respective interests. He indicated that he frequently travelled through Brassov. I invited him to come and stay with me whenever he was in the area. This invitation began an unexpected relationship with him as I turned my attention to surveying the Roma with him and participated in Gheorghe's effort to organize Romania's Roma into a recognizable ethnic group out of disparate and disjointed members of socialist Romania's most impoverished, deprecated, and racialized class.

In my travels through the Olt valley and beyond, I was struck by Roma who inevitably located their homes, small shacks, at the edge of ethnic Romanian villages, referred to by Romanians as a mahala. Nicolae invited me to join him in his own fieldwork and activism. During visits and our travels together we engaged each other about the Roma and economic specialization and he said the best way to discuss this is to see them for myself. This was the start of a friendship and my developing interest in Roma. As my attention to Roma expanded, Nicolae provided me with Romanian published sources about the Roma. He often went to a great deal of trouble to photocopy material for me, something that the authorities would find suspicious and an activity that put him into jeopardy. 
The more I observed and the more I read of the history of Roma, slavery and indentured servitude, the racialization of their identity, Romanian racism and xenophobic attitudes, Roma immiseration, forced sedentarization of migratory groups, their various levels of assimilation and enculturation, the more interesting they became for me. I sensed that our intense discussions as well as those he had with others he drew into his circle influenced how he conceptualized his own work.

As I engaged Roma, I found them to have a sense of integrity and openness I did not expect. Most all I encountered, especially those who had been sedentary for hundreds of years, sought out a living however they could. In rural settings, even the poorest of them carried themselves with dignity. Others, often those who until the socialist era, had been migratory with specific trades, such as metal workers of all types, had a different status altogether. The extraordinary diversity among the Roma was astounding to me.

For Nicolae, the Roma were a personal mission, not only an object of study. I speculated that his understanding of the peril the authorities posed, stepping in to curtail his activities with the Roma, but also with me, only made him eager to pursue his interests. He was seeking to organize the Roma into a political force. He was community organizing across a highly diverse and segmented population identified as țigani into a cohesive group as "Roma." In doing so, he wanted the State to recognize the Roma as a coinhabiting nationality and with this legitimacy and recognition would be gained in a country where ethnic Romanians perceived them as unwelcome outsiders. Their centuries-long period of slavery (Beck, 1989) in Romania and their contributions to the land was ignored.

Nicolae's work also entailed a discovery of himself. He spoke openly about having been raised isolated from the Roma. He did not speak Romani and knew little about them before he started his research. In our intense discussions, he consistently reflected on how his own identity was shifting and changing as he carried out his work and as he learned more about the diverse populations referred to as tigani (Beck, 1993). I was reminded of W. E. B. Du Bois' notion of double consciousness (1994), a condition in which oppressed people look at themselves through the eyes and conceptual framework of the oppressor and internalizing the contempt associated with it. Franz Fanon (1986) addressed double consciousness as well. In Fanon's view, blacks are positioned by whites to accept their stereotyped notions of who they are and accepting this position by behaving in the expected manner. The stereotype becomes reality. Gramsci (2000; Adamson, 2014) identified something similar. He saw the power of bourgeois society in which culture, ideas and beliefs, is shaped and reproduced by media, universities and religion to produce consent and legitimacy, leaving little or no room for dissent or counter-hegemony. Revolution would emerge from the working class as they created an alternative vision of themselves and society. 
Nicolae struggled with his sense of himself as a Romanian, an identity that his phenotype belied and how ethnic Romanians treated him as a result, no matter his intellectual brilliance. This kind of struggle was familiar to me because of the racial history in the United States that targeted groups of people by what they looked like as outsiders and not belonging as the "strangers" in our midst. The irrational racialized animus toward tigani was no different, in my eyes, as the racialized animus toward people of color in the United States.

We had endless discussions about what discoveries we made, how to understand the dismal conditions in which the vast majority lived and what to do about it. How similar are the experiences of Roma to the descendants of African slaves, or that of indigenous people. How do we change how many Roma saw themselves and identified themselves as țigani. Nicolae was particularly puzzled about how to bring about a Roma identity among those groups who clearly were of Roma descent but did not identify as such and often enough rejected this idea.

\section{Dimitrie Gusti}

This was also a time when I fixed my interests on Romanian scholarship, especially the work of Dimitrie Gusti's Romanian Social Institute, reading the monographs produced by Dimitrie Gusti's students. The work on Drăguș was particularly important to me. I met Henri Stahl, a preeminent Romanian sociologist with an international reputation and one of Gusti's students and started to read his work. I also spent time with Traian Herseni, another of Gusti's students who proved to be helpful. Meeting them and learning about who they were during the inter-war period gave me a unique insight into the complexities of the political environment of that time, Stahl being on the socialist Left side of the political spectrum and Herseni on the Right side, an Iron Guardist before Romania became part of the Sovietized frontier. In my estimation, Gusti's and his student's intense research of Romanian peasant life has not been equaled. It is an extraordinary body of work, appreciated and carried forward by Michael Cernea with great difficulty while in Romania and with much success and recognized by applied anthropologists as he worked for the World Bank $(1970,1985)$.

I found Nicolae following the Gusti tradition of active engagement with communities, seeking to document in the traditional ethnographic manner while simultaneously bringing about change. He was studying "them" and selfreflecting on his identity creating a tension that personalized his research. He lived that tension because he could not distance himself enough to objectify in the manner of more traditional ethnographic research. In present day anthropology we would refer to this as engaged anthropology (public, advocate, activist, or participatory action anthropology). This kind of research method is clearly not 
value free, nor should it be. It is one important anthropological approach that places the anthropologist into the position of change agent in the service of vulnerable populations and using this position in knowledge production.

\section{From Persona Non Grata to Rebellion in the Streets}

Once I was able to stabilize my career in the United States by accepting a position at Cornell University, I was able to visit Romania a number of times. Once, right before the fall of the communist regime, while at a conference in Belgrade, I took a train to Bucharest. I crossed into Romania without an incident, but when the border control took my passport for clearance, they did not return it until we came to the first stop into Romania. I was guided off the train, placed into a holding cell overnight and told, "you are a persona non grata." I returned to Belgrade in the morning (Beck, 1992b).

That was the end of my Romanian research until the fall of the Ceaussescu regime. I visited Romania as rebellions took place in Bucharest. I was present at several critical moments, witnessing the mob-takeover of the television station in Bucharest. I was present as large lories filled with coal miners drove through the city waving their truncheons, threatening people and violently thrashing them, at especially young demonstrating men. I was present in University Square where people gathered, some camped out, and numerous recovering from severe beatings.

I beheld with astonishment and anguish the many young people bandaged, bleeding, and crippled camped out and milling about in University Square adjacent to the Intercontinental Hotel. I found myself in the square and in the streets seeking to grasp what was happening as thousands of people milled about, moving in one direction and then suddenly moving into another in mob behavior all day long and into the night and early morning (1991a, 1991b, 1991c).

\section{Cape Verdeans}

When I returned to the United States in 1981 from my post-doctoral Romanian research, I accepted a post-doctoral position in alcohol studies with Dwight Heath of Brown University's Anthropology Department. Part of my assigned work included local fieldwork in Providence, Rhode Island. I chose to carry out research in a bar that locals identified as a "black bar" in the Brown neighborhood called Fox Point where Cape Verdeans made their home for over 100 years. This is an area close to the campuses of Brown University and the Rhode Island School of Design with some of the oldest houses in Providence dating to the eighteenth century. 
Providence city planners targeted Fox Point for urban renewal to remove areas of "blight" and the construction of a modern highway. A historic preservation movement emerged to preserve these valued properties representing Providence's early history, preventing them from being demolished. A dramatic rise in the cost of real estate followed as did the displacement of the low-income Cape Verdeans who lived there and who experienced this process, in their words, as "nigger removal." These were people from the former Portuguese Islands off the coast of West Africa. Their way of life was shattered by displacement as their neighborhood was being gentrified because they no longer could afford rising rents.

Here is where I met my second wife, who was a community organizer working with the Cape Verdean community. I came to participate in the activism involved in resisting gentrification by slowing down and limiting gentrification. I consciously followed an engaged ethnographic agenda, deciding to do what Nicolae Gheorghe did, by becoming an ally with the Cape Verdean struggle for their neighborhood and use my activism to generate the data for my book, Manny Almeida's Ringside Lounge: The Cape Verdean Struggle for their Neighborhood (1992a). I came to personalize the struggle in which Cape Verdeans were involved, their struggle in fighting the injustice of gentrification was also my struggle.

I participated with Cape Verdeans in acts of peaceful resistance, creating public programs to inform the general public about the displacement impact gentrification was having and who or what was involved in creating these conditions. My book was written for the Cape Verdean community to legitimize their claim to the neighborhood, lest the gentrifying newcomers forget who preserved the coveted housing of the eighteenth and nineteenth centuries, housing that now was valued with increasing prices representing early America history and society.

My experiences with and about the Roma directly played into my Cape Verdean research, advocacy, and activism. Almost all of my graduate student work was focused on Europe and the Balkans as was my personal history, as a child of intergenerational refugees from anti-Semitism and war, Russia, China, and Austria. I took the racism and classism experienced by Roma and Cape Verdeans personally, as an assault on my own humanity.

\section{Critical Consciousness}

I explored a critical and activist anthropological method not only because it was a novel approach to anthropological research but as a moral commitment to participate in social change. I came to realize that anthropological research 
methods have a colonial aspect to them in the sense that participant observation is an approach for harvesting information without making meaningful contributions to the people being researched. Whatever the intentions of any one anthropologist using standard ethnographic research methods, they are exploitative in their very nature (Smith, 1999).

Customary research is about people, objectifying them, their culture and behaviors, and the challenges of life they face. What Nicolae Gheorghe modeled in his work, and what the Gusti School of Sociology demonstrated was an epistemological approach that I sought to emulate and apply to current conditions. Clearly, of the volume of research anthropologists carry out, most of it is about the most vulnerable in society. Moreover, the publications we have produced, with some exceptions, have little relevance to the people we study; it is for internal consumption and oriented to further our discipline and of course our individual careers.

A movement emerged in the social sciences influenced by feminist theory and the notion that the "personal is political," critical anthropology with its attention to reflexive critique of the discipline and political economy ${ }^{5}$. I came to use these orientations to focus my personal struggle and that involved a search for my identity in the research process and my involvement in the struggle with others for dignity and emancipation.

By the time I came to know Nicolae Gheorghe, he saw himself as an assimilated Romanian with no ties to Roma, linguistically or culturally, to others he was a tigan because of what he looked like. He knew it was something from which he could not escape even if he wanted to. Notwithstanding the fact that any Romanian who saw him could identify him as țigan, he viewed, at least at the start, the Roma with whom he was involved as the "Other." It was only as his experiences with Roma moved him from perceiving Roma as "them" to "us" that who he was as seen by others took on a different dimension.

What Gheorghe was experiencing was what W. B. Du Bois called double consciousness (1994) and the process by which he made his discovery, is what Paolo Freire referred to as critical consciousness (conscientizacao). According to Freire, "The term conscientizacao refers to learning to perceive social, political, and economic contradictions and to take action against the oppressive elements of reality" (1968: 19). In a book he published a year later, Education for Critical Consciousness (1969), Freire expanded on this idea as an ontological project. Here he elaborated on critical consciousness as the means for liberation. Through a process that Donald Schoen (1983) much later identified as reflective practice, Freire, already in 1969 used his term, critical consciousness, to identify

\footnotetext{
5 There are individual predecessors to this approach, such as Sol Tax (1958).
} 
a process of continuous learning by which the oppressed identify the impositions of power by the elite and the State as cultural norms. Furthermore, cultural norms reproduce a status quo (Gramsci, 2000), based on racism, xenophobia, and classism, which Nicolae Gheorghe was attempting to change. He was creating an anti-hegemonic Roma strategy that provided a positive Roma identity replacing the deleterious identity given them by the majority population in Romania and Europe.

\section{North Brooklyn}

It was this kind of project in which I involved myself with the Cape Verdean struggle to sustain their community and the web of social relations that shaped their identity. The political will of the city combined with the interests of privileged institutions of higher education too close in proximity to low income people of color and the fear that it aroused among affluent students and their parents. This combined with efforts of historical preservationists to focus on the built environment instead of the people who lived in the valued housing over the generations overpowered the Cape Verdean struggle. However, that people united in common cause created the conditions for empowerment, at least for the period in which Cape Verdean still had a presence in the neighborhood. People learned to organize and experienced self-empowerment.

When I moved to New York City, I continued this kind of work as I sought to support those who suffered the consequences of oppressive conditions over which they had little control and through dialogic means gain critical consciousness and empowerment. I sought to work with vulnerable populations in their efforts to gain justice, a voice and a place at the table to make decisions for themselves that impact their lives. This was not only a political stance, although it was that too, but one of a changing anthropological methodology.

In the process of working with students who involved themselves in internships, a form of apprenticeship or practicum learning in the USA, and community-service learning, for students to experience leadership, volunteerism, and citizenship development (2000, 2002, 2005, 2006), I established a close working relationship with a number of community-based organizations (CBOs) in North Brooklyn and became an Executive Board member in four of them (Beck, 2018). Much of North Brooklyn, Williamsburg, Bushwick, and parts of Bedford Stuyvesant had a population of people of Hispanic descent (Latinos). Their situation in their neighborhoods, much like that of Cape Verdeans, was in peril because capital poured into the area for the development of high-end luxury housing and producing dramatically large increases in rents. Low-income people, who could not afford these increases, were displaced as fast-paced gentrification 
rushed through the area like a tsunami. Over the course of a decade, Williamsburg alone lost over ten thousand Latinos, as much as two-thirds of its Latino population. From a human rights perspective, this was nothing short of a localized campaign of ethnic cleansing, legitimized by neoliberal market force principles.

Since the sixties and seventies, Latino-based community organizations created a web of services that sustained low-income people of color in their neighborhood populated after WW II and into the present. Over a period of two decades, my own participation with them produced a body of work that only in small part is academic in the sense that it led to publications (Beck 2006, 2015b, 2018). The other part is what I term invisible public anthropology. Invisible because part of what public anthropologists do is participate in discussions with people and share anthropological insights with organizations, involve themselves in their processes, as we participate in making decisions and organizational policies that direct change. Our contributions cannot be measured in any academically viable manner, hence invisible. Our contributions are invisible to the people we work with as well because as allies we are coparticipants in activities sharing our expertise as much as every other participant. These interests and work led to my collaboration with Carl A. Maida (UCLA) who was involved in similar efforts in Los Angeles. Our association led to the publication of a series of edited volumes, Toward Engaged Anthropology (2014), Public Anthropology in a Borderless World (2015a), and Global Sustainability and Communities of Practice (2018). I am now working on a manuscript that focuses on inter-group relations among Hipsters, Hispanics, and Hasidim (ultra-Orthodox Jews), gentrification, and the displacement of Latinos from a social history and activist anthropology point of view. This project emerged as a consequence of taking my students to North Brooklyn and integrating them within community-based organizations, with which I was personally associated, to carry out community service and to learn from their experiences with low-income people of color.

\section{Some Conclusions}

Nicolae Gheorghe died August 8, 2013. In 2014 I participated in a conference in Bucharest commemorating Nicolae Gheorghe's contributions to Romani Studies and the Romani human and civil rights movement. ${ }^{6}$ On this occasion, I met Nicoleta Bițu, Nicolae's wife and partner, a political scientist and

\footnotetext{
${ }^{6}$ Roma Policies in Romania: Between Ethnicity and Social Vulnerability: The Perspectives of Nicolae Gheorghe. August 5-7, 2014. Bucharest, Romania, Roma Cultural Museum.
} 
leader in the Roma movement in her own right as president of the Democratic Federation of Roma from Romania and a founding board member of the European Roma Institute for Arts and Culture (ERIAC) located in Berlin. I was given a tour of the emerging Roma Cultural Museum in Bucharest and was reminded of the conversations I had with Nicolae about honoring Roma artistic and craft traditions in this manner and raising into prominence the contributions Roma made to Romanian society, starting with their time under conditions of slavery.

This was also the occasion when I met Roma anthropologist and activist Ciprian Necula, Nicolae's student, whom he mentored to carry on his work. At this conference I gave voice to the impact Nicolae had on me and how he influenced my career. Bernard Rorke neatly summed up Gheorghe's contributions (2015): "As an engaged cosmopolitan public intellectual, an activist and a diplomat, a humanist and an indefatigable defender of fundamental rights, Nicolae's contributions inspired and informed all who encountered him." These words certainly ring true to me as the next generation of Roma continues in his footsteps, hopefully recognizing the debt they owe him.

I met Ana Ivasiuc at this meeting and we agreed to publish a book on Romani activism to honor Nicolae Gheorghe's legacy and point it into the future. After some debate, we decided to call it, Roma Activism: Reimagining Power and Knowledge (2018). Predictably, in this book issues of race, racism, xenophobia, displacement, and violence appear and less predictably gender. Here a mix of Roma and non-Roma scholars represent their work. We intentionally sought out scholarship by Roma in part to reject the view by some in Romani Studies that Roma identifying scholars could not and were not qualified to and should not carry out research among their own people. This is an old and flawed argument dismissed by anthropologists long ago. Moreover, the issue of female Roma scholars also was brought into view as they are challenged by racism and misogyny within some quarters of the academy where they are employed.

The academy, as much as the whole society, must be able to transcend the present conjuncture so dominated by capitalist neoliberal economic ideology and practice in which racism and xenophobia are embedded in nationalist fervor further victimizing the most vulnerable. A capitalist mode of production that seeks to commoditize everything to produce profits for corporations and those already affluent has penetrated universities. Education is now a commodity in an economy where knowledge is a product bought and sold to benefit industry, business, the competitive capacities of the State and the few "stars" in the academia. The research university is a business increasingly tied to, intersecting with, and beholden to government, foundation, and corporate funding. 
This reality cannot and should not hold. Anthropology and other disciplines in the humanities and the social sciences are shrinking departments. To survive, research universities are assigning these disciplines to support STEM fields, science, technology, engineering and math. If this process holds, while this may be a necessary short-run adaptive response to the neoliberal mode of production, anthropology is demonstrating its resilience by surviving along the edges of other more profitable disciplines, for example medicine, business, marketing and advertising, design, journalism, the military, and so on.

In the long run, the anthropology I have been talking about in this text also must be practiced outside the academy by serving the most vulnerable we as anthropologists choose as objects of study, participating with them to improve their lives. It is not unusual for anthropologists to be found in community-based organizations (CBOs), NGOs, and a variety of foundations and government agencies. The approach I favor with my position in a university is a product instigated by my experiences in Romania, reinforced by my action and activist research and the influences of action, activist, public and engaged anthropologist predecessors.

In the process of carrying out our academic roles to ensure our own subsistence and continuity, those of us who choose to carry out this kind of work, whether in the academy or outside of it, must simultaneously engage local knowledge producing communities, those most vulnerable in society, within public spheres and civil society. This is done by promoting the conditions for collaboration and mutuality to address the specific problems impacting them and their communities through acts of self-organization, the production of alternative and anti-hegemonic discourses, and the co-production of liberating knowledge and practices.

This would be a commitment to a non-hierarchical, non-knowledgeharvesting approach. Instead, we use a participatory web-like, social-networking method for knowledge production that is congenial and non-competitive with the purpose of intersecting engaged research and experience-based learning with direct action to improve the human condition. This synergistic social process and culture would generate renewable foundations for radical democratic praxis pushing back against individualization, the hyper-competitiveness that has produced wars and the unhinged grab for domination. This approach is anchored in teaching and learning as a reciprocating dialogic process, in-context and inprocess within a knowledge producing commons. Our roles as teachers, researchers and activists must not be defined only by giving voice to the voiceless or explaining why and how things happen, or resistance to oppression, infringements on human and civil rights and hegemonic regimes. We must be actively engaged in reformulating the reality in which we find ourselves and engage students and the public to envision and create a different future than the self-destructive course our planetary leadership has chosen at this time. 


\section{REFERENCES}

Adamson, Walter L. (2014). Hegemony and Revolution: A Study of Antonio Gramsci's Political and Cultural Theory. Brattleboro, Vermont: Echo Point Books and Media.

Barth, Fredrik (1961). Nomads of South-Persia: The Basseri Tribe of the Khamseh Confederacy. Boston: Little Brown and Company.

Barth, Fredrik (1969). Ethnic Groups and Boundaries: The Social Organization of Cultural Difference. Boston: Little, Brown.

Beck, Sam (1976). The Emergence of the Peasant Worker in a Transylvanian Mountain Community. Dialectical Anthropology. 1: 365-375.

Beck, Sam (1979). Transylvania: The Political Economy of a Frontier. Ann Arbor, MI: University Microfilms International.

Beck, Sam (1989). The Origins of Gypsy Slavery, Dialectical Anthropology, 14: 53-61.

Beck, Sam (1991a). Toward a Civil Society: The Struggle Over University Square in București, Romania, June 1990. Socialism and Democracy. 13: 135-154.

Beck Sam (1991b). "Contested Space: The Symbolic Nature of the Romanian Revolution in 1990." Working Papers on Transitions from State Socialism: Cornell Project on Comparative Institutional Analysis; Center for International Studies, Cornell University.

Beck, Sam (1991c). What Brought Romanians to Revolt. Critique of Anthropology. 11(1): 7-31.

Beck, Sam (1992a). Manny Almeida's Ringside Lounge: The Cape Verdean Struggle for their Neighborhood. Providence, RI GAVEA-Brown Publications.

Beck, Sam (1992b). Persona Non Grata: Ethnicity and Romanian Nationalism. In Christine Gailey, Ed., Dialectical Anthropology: Essays Presented to Stanley Diamond. Gainsville: University of Florida Press.

Beck, Sam (1993). Racism and the Formation of a Romani Ethnic Leader. In George E. Marcus, Ed., Perilous States: Conversations on Culture, Politics and Nation. Chicago: University of Chicago Press.

Beck, Sam (2000). Community Service Learning: Where is Anthropology? Anthropology News, Society for the Anthropology of North America. October.

Beck, Sam (2002). Radicalizing Anthropology: Community Service Learning. Special Issue, The Anthropology of Work Review, Society for the Anthropology of Work. XXII (2).

Beck, Sam (2005). Community Service Learning. Bulletin of the General Anthropology Division. 12: 1-2.

Beck, Sam (2006). Introduction: Experiential Learning, Lived Practice and Knowing-InAction. In Sam Beck, Ed., Special Issue. The Anthropology of Work Review, Society for the Anthropology of Work. XXVI (2): 1-5.

Beck, Sam (2006). Healthy Wednesdays in Our Hood. In Hofman, Nila Ginger and Howard Rosing, (Eds.). Pedagogies of Praxis: Interdisciplinary Perspectives on Course-Based Action Research. Boston, MA: Anker Publishing. 
Beck, Sam and Carl Maida, Eds. (2014). Toward Engaged Anthropology. New York: Berghahn Books.

Beck, Sam and Carl Maida, (Eds.). (2015a). Public Anthropology in a Borderless World. New York: Berghahn Books.

Beck, Sam (2015b). Urban Transitions: Graffiti Transformations. In Public Anthropology in a Borderless World (co-edited with Carl Maida), 314-350. Brooklyn: Berghahn Books.

Beck, Sam (2018). Knowledge Production and Emancipatory Social Movements from the Heart of Globalized Hipsterdom, Williamsburg, Brooklyn. In Carl Maida and Sam Beck, (Eds.). Global Sustainability and Communities of Practice, 125-150. Berghahn Books: New York.

Beck, Sam and Ana Ivasiuc (2018). Roma Activism: Reimagining Power and Knowledge. New York: Berghahn Books.

Cernea, Mihail, Gheorghe Kepes, Maria Larionescu, et al (1970). Două sate: Structuri sociale şi progres tehnic [Two Villages: Social Structures and Technical Progress], București: Editura Politică.

Cernea, Michael M., Ed. (1985). Putting People First: Sociological Variables in Rural Development. New York and London: Oxford University Press.

Cole John W. and Eric R.Wolf (1974). The Hidden Frontier: Ecology and Ethnicity in an Alpine Valley. New York: Academic Press.

Du Bois, W. E B. (1994). The Soul of Black Folk. New York: Gramercy Books.

Fanon, Franz (1986). Black Skin, White Masks. London: Pluto Press.

Freire, Paolo (1968). Pedagogy of the Oppressed. New York: The Seabury Press.

Freire, Paolo (1969). Education for Critical Consciousness. New York: Continuum.

Gramsci, Antonio (2000). The Antonio Gramsci Reader: Selected Writings 1916-1935. New York: New York University Press.

Hymes, Dell (1974). Reinventing Anthropology. New York: Pantheon.

Maida, Carl and Sam Beck, (Eds.). (2018). Global Sustainability and Communities of Practice. New York: Berghahn Books.

Nader, Laura (1969). Up the Anthropologist: Perspectives Gained from studying up. In Dell Hymes, Ed., Reinventing Anthropology. New York: Random House.

Rorke, Bernard (2015). "Remembering Nicolae Gheorghe." European Roma Rights Center (ERRC). http://www.errc.org/blog/remembering-nicolae-gheorghe/18. [retrieved 8/24/18].

Schoen, Donald A. (1983). The Reflective Practitioner: How Professionals Think, New York: Action. Basic Books.

Smith, Linda Tuhiwai (1999). Decolonizing Methodologies: Research and Indigenous Peoples. London: Zed Books.

Steward, Julian H., Ed. (1956). The People of Puerto Rico: A Study in Social Anthropology. Illinois: University of Illinois Press.

Tax, Sol (1958). Values in Action. Human Organization, 17(1). 